\section{Hybrid Mantle invoked to correlate Vitória-Trindade Ridge Origin to Reaction-pyroxenite from subducted ancient oceanic eclogite slab.}

\author{
ANDERSON COSTA DOS SANTOS ${ }^{1}$, EDUARDO VIANA- \\ JÚNIOR $^{2}$, PROF. PETER HACKSPACHER SR., PHD ${ }^{3}$ AND \\ MAURO CÉSAR GERALDES ${ }^{1}$ \\ ${ }^{1}$ UERJ \\ ${ }^{2}$ UFBA \\ ${ }^{3}$ Rio de Janeiro State University (UERJ) \\ Presenting Author: andcostasantos@gmail.com
}

Much debate surrounds the geodynamic and genetic process that gives rise to lithological and chemical heterogeneities of the mantle over a wide range of scales observed from the analysis of oceanic rocks. Some models invoke mantle plumes originating in the mantle-core boundary or in the $660 \mathrm{~km}$ seismic discontinuity to explain these chemical and isotopic variations observed in ocean rocks. Alternative models include melting of pyroxeniteperidotite mixtures in the shallow mantle, as well as metasomatic agents, as a result of the recycling of subducted slabs and upper mantle metasomatic processes. Vitória-Trindade Ridge (VTR) offer a means of testing this alternative model because they are interpreted as originating from an upper mantle source that includes recycled subducted components.

Based on geochemical and isotope data from VTR rocks $\left({ }^{87} \mathrm{Sr} /{ }^{86} \mathrm{Sr}_{\mathrm{m}}=0.70366-0.70404,{ }^{143} \mathrm{Nd} /{ }^{144} \mathrm{Nd}_{\mathrm{m}}=0.51262-0.51282\right.$, $\left.{ }^{206} \mathrm{~Pb} /{ }^{204} \mathrm{~Pb}_{\mathrm{m}}=18.865-19.168\right)$, it seems likely that these rocks have been generated from a source consisting of different proportions of peridotite and olivine-poor components (e.g., pyroxenite, garnet pyroxenite, or eclogite), which occur by partial melting of the MORB-eclogite and injection of its silicic melts into the surrounding peridotitic mantle, yielding a hybrid pyroxenite. Note that the high- $\mathrm{TiO}_{2}$ contents of the VTR rocks, along with the depletions in $\mathrm{Rb}$ and $\mathrm{K}$ in relation to fluidimmobile incompatible elements like $\mathrm{Hf}, \mathrm{Zr}, \mathrm{Ti}, \mathrm{Nb}$ and $\mathrm{Ta}$ are robust evidences for recycled oceanic crust component in the mantle source, as well as a consequence of oceanic crust dehydration during subduction. In addition, the VTR rocks have low $\mathrm{SiO}_{2}\left(\mathrm{SiO}_{2}=38.5-40.5\right.$; for samples with $\mathrm{MgO}>10 \mathrm{wt} . \%$ to minimize effects of clinopyroxene crystallization) and high ${ }^{206} \mathrm{~Pb} /{ }^{204} \mathrm{~Pb}$ ratios, which can be reconciled if its source has been metasomatized by carbonatitic liquids from recycled carbonated ocean crust (a component that may contain high $\mathrm{U} / \mathrm{Pb}$ and $\mathrm{Th} / \mathrm{Pb}$ ratios).

Addressing the source composition of the VTR rocks, a trace element partial melting model was performed indicating the presence of small amounts of Si-rich melts (up to 9\%) formed from partial melting of MORB-eclogite and carbonatite liquid (up to $0.1 \%$ ) derived from recycled carbonated ocean crust in the peridotite mantle, represented by DMM.

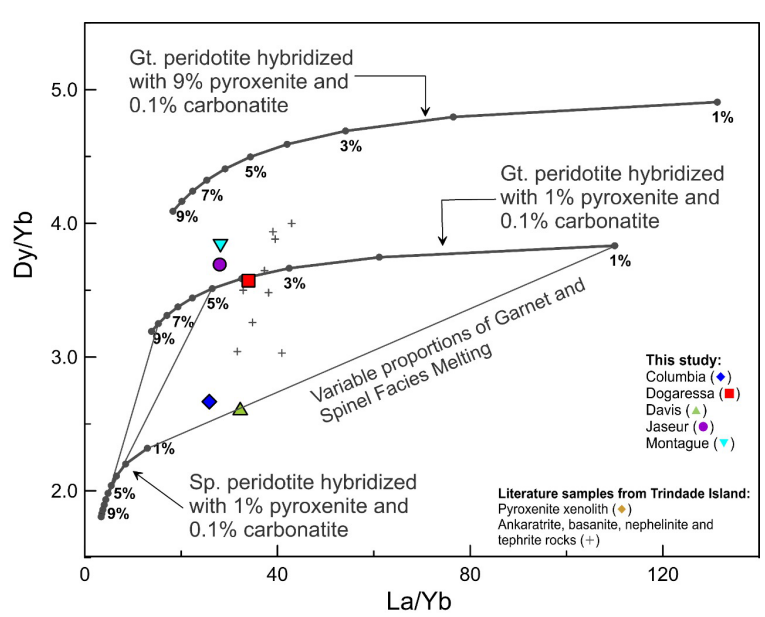

